\title{
Role of Financial Efficiency and Income Distribution on the Relationship Between Economic Growth on Poverty Levels in East Africa Community Countries
}

\author{
James Mageto Nyamweya ${ }^{1, *}$, Michael Ochieng Obuya ${ }^{2}$ \\ ${ }^{1}$ Department of Finance and Accounting, Faculty of Business, University of Nairobi, Nairobi, Kenya \\ ${ }^{2}$ Department of Finance, Accounting and Economics, Faculty of Business, Jomo Kenyatta University Agriculture and Technology, Nairobi, \\ Kenya
}

Email address:

jamesnyamweya18@gmail.com (J. M. Nyamweya), obuyamike@gmail.com (M. O. Obuya)

${ }^{*}$ Corresponding author

\section{To cite this article:}

James Mageto Nyamweya, Michael Ochieng Obuya. Role of Financial Efficiency and Income Distribution on the Relationship Between Economic Growth on Poverty Levels in East Africa Community Countries. International Journal of Finance and Banking Research. Vol. 6, No. 4, 2020, pp. 65-73. doi: 10.11648/j.ijfbr.20200604.12

Received: May 27, 2020; Accepted: June 15, 2020; Published: July 23, 2020

\begin{abstract}
The study examined the relationship between economic growth, income distribution and poverty levels in East African Community countries. The specific objectives of the study included establishing the effect of economic growth on poverty levels in EAC countries and examining the moderating effect of income distribution on the relationship between economic growth and poverty levels in EAC countries. The study adopted both comparative and descriptive research designs. The study population was the five countries of EAC countries which included Kenya, Rwanda, Uganda, Burundi, and Tanzania. Annual data for 30 years beginning 1989 to 2018 was gathered for the study purpose. Secondary data, which consisted of annual data, was utilized in the study. The study employed normality, heteroscedasticity, multicollinearity, serial correlation, Optimal lag test, unit root diagnostic tests, cointegration test and cross sectional correlation test. The data was analyzed using both descriptive and inferential statistics with the help of excel and STATA version 14. Feasible Generalised Least Squares (FGLS) panel data regression models was used for hypotheses testing. The study results revealed that economic growth had a significant effect on poverty levels in East African Community countries. In addition, the study revealed that income distribution has a significant mediating effect on the link between economic growth and poverty levels in East African Community countries.
\end{abstract}

Keywords: Financial Efficiency, Economic Growth, Income Distribution and Poverty Levels

\section{Introduction}

Globally, the economic problem of poverty has been an area of concern for decades as world economies pool their resources to fight poverty. Various policies have been developed based on theoretical studies on the determinants of poverty [1-2]. Obuya and Olweny (2017) stated that one of the policy areas has been the income distribution front based on the inequality-poverty nexus literature. The association between economic growth, income distribution and poverty levels in national economies has been an area of concern for scholars in both the developed nations and developing counterparts [3]. Even though Africa has experienced economic growth since 2003, the continent still has high levels of poverty because almost half of the population earns below $\$ 1.25$ per day. This challenge is even more prevalent in EAC Countries community because effort geared towards reducing income disparity is minimal [4]. Over the last three decades, worldwide poverty levels have fallen greatly from $40 \%$ to under $20 \%$, but the poverty levels in African countries have almost remained the same in the same period under review. Over $40 \%$ of the people who live in the Sub-Saharan Africa live in abject poverty [5]. Various policies to combat poverty have been introduced in most EAC countries for instance Kenya introduced the National Poverty Eradication Plan (1999-2005). Under this program, the government hoped to eradicate poverty by 2015 [6]. This study, therefore, attempted to address knowledge gap in the 
literature. Most of the studies that examine the effects of economic growth on reducing poverty in the EAC region focus on individual countries. They have limited application in the context of EAC countries as a whole [7-11]. Additionally, the majority of studies have ignored mediating effect of income distribution on the association between economic growth and poverty which is contrary to the growth-finance-poverty nexus literature [12-14]. The study therefore sought to bridge the gap in literature by examining the moderating role of income distribution on the relationship between economic growth and poverty levels in East Africa Community Countries.

\subsection{Research Objectives}

1. To establish the effect of economic growth on poverty levels in EAC countries.

2. To examine the mediating effect of income distribution on the relationship between economic growth and poverty levels in the EAC countries.

3. To examine the moderating effect of financial efficiency on the relationship between economic growth and poverty levels in the EAC countries.

\subsection{Research Hypotheses}

1. Economic growth has no significant effect on poverty levels in EAC countries.

2. Income distribution has no significant mediating effect on the relationship between economic growth and poverty levels in the EAC countries.

3. Financial efficiency has no significant moderating effect on the relationship between economic growth and poverty levels in the EAC countries.

\section{Literature Review}

\subsection{Theoretical Review}

Liberal Theory: Liberal theory revolves around the idea that poverty in an economy is caused by both market distortions and underdevelopment in various areas. This theory was formulated by Keynes who believed that market forces were capable of promoting economic growth and in turn eradicate poverty [15]. Based on this belief, Keynes justified government's interventions at macroeconomic level especially in handling involuntary unemployment. From a liberal perspective, poverty is defined as the misfortune of a small group of people who cannot work even if they wished to work. As a consequence, governments should regulate as opposed to impose its rule on poverty reduction [16]. The liberal theory argues that poverty can be used to reflect the extent to which market forces fail to justify redistributive taxation in kind and cash. In line with the argument above, liberal theory holds that economic growth has the capacity to improve per capita income of the population that results in reduced poverty levels. An expanding economy through economic growth also leads to reduced unemployment that enables households to afford basic goods needed to support life. Economic growth thus is very critical in poverty reduction at the microscopic and macroeconomic level.

The Public Choice Theory of Distribution: Buchanan was the first person to propose the Public Choice Theory of Distribution [17]. The theory claims that income distribution can be critical in redistributing resources in countries that have high levels of income disparity [18]. In proportion to this argument, the first fundamental economic theory presupposes that competitive market economies are able to provide effective means that can be utilized to allocate resources to Pareto's optimal point [19]. Such an allocation would not make certain people better than others meaning that all people would be equal. The theory identifies the role of income distribution in redistributing resources in countries that have high levels of income disparity hence leading to poverty reduction.

\subsection{Empirical Review}

Various empirical studies exist on connection between economic growth, poverty and income inequality. Reference [20] analyzed data spanning from 1980 to 2004 showed that income elasticity of poverty kept on declining. In addition, he found out that poverty income elasticity was less than income inequality's responsiveness. The study ignored economic growth as a variable in the model in addition to using income inequality as an independent variable instead of a mediating variable. Reference [21] carried out a review of empirical literature connection to income distribution, poverty and economic growth. The Study never, however, established any precise connection between economic development and expanding income disparity. Nations that have been fruitful as far as economic development is concerned are in all respects effective in decreasing poverty influence.

Reference [22] examined the level of income inequality and the role that policies developed toward income inequality played in reducing poverty. The outcomes demonstrated that because of high-income imbalance in Kenya, stimulation of development in rural and manufacturing parts of the country essentially was more advantageous to the urban family unit since they own most of the factors of production. Reference [22] has limited application to Kenya in addition to using income distribution as independent variable instead of mediating variable. Reference [23] examined the link between poverty, income inequality and trade liberalization. He established that trade liberalization had a significant impact on poverty and income distribution, but the impact was negligible and conveyed unequally. In spite of this, [23] ignored economic growth as a variable in the model and used trade liberalization in place of economic growth.

Reference [12] analyzed the association between Poverty, property rights and Financial Deepening Sub-Saharan Africa countries. The Data was from 37 countries in Africa from 1992 to 2006. The study used panel data regression model. Study showed that poverty, financial deepening and income inequality were significantly related. It specifically showed that financial deepening was able to increase income inequality thereby increasing poverty that is contrary to 
finance- poverty nexus. In addition, the study only considered direct effect of financial deepening on poverty thereby ignoring the indirect ones. Reference [24] analyzed the connection between income distribution and financial development proxies. Utilizing selected 143 nations and analyzing data covering the period 1961 to 2011. The research established that financial development proxies fundamentally lessened poverty and income inequality. Reference [24] used income distribution as dependent variable instead of using it as a mediating variable. In addition, [24] ignored economic growth in the analysis model. Reference [20] examined the link between economic development poverty in less developed nations, with attention to the role of income inequality. The empirical examination found that out growth of income has largely been significant in the changes in poverty.

Reference [25] examined the effects that tax and government expenditure had on poverty and income distribution within Argentina using data spanning from 2012 to 2013. The outcomes of the study demonstrate that monetary and fiscal strategy has been an incredible asset in decreasing income imbalance and poverty. However [25] used government expenditure in the place of economic growth as an independent variable in addition to the study having limited application to Argentina.

\section{Methodology}

\subsection{Research Design and Population}

The study adopted a descriptive and comparative research designs. Since the study intends to compare the relationship between study variables across the five countries in East African Community, comparative research design is the most appropriate. The study population was five countries in the EAC, which included Kenya, Rwanda, Uganda, Burundi, and Tanzania. South Sudan was omitted because it is not a full member of the EAC. Annual data for 30 years beginning 1989 to 2018 was gathered for the study purpose. Secondary data, which consisted of annual data, was utilized in the study. The data relating to real GDP, headcount ratio and Gini coefficient were acquired from the World Bank and African Development Bank websites. The study collected annual data for 30 years from 1989 to 2018 from five EAC countries. The variables were operationalized as shown in table 1 .

Table 1. Definition and Measurement of Variables.

\begin{tabular}{|c|c|c|c|}
\hline Variable & Notation & Proxy & $\begin{array}{l}\text { Expected } \\
\text { Sign }\end{array}$ \\
\hline $\begin{array}{l}\text { Dependent variable } \\
\text { Poverty } \\
\text { Independent variable }\end{array}$ & $\mathrm{Y}$ & Head Count Ratio & \\
\hline $\begin{array}{l}\text { Economic growth } \\
\text { Mediating Variable }\end{array}$ & $\mathrm{X}$ & Real GDP & $(-)$ \\
\hline $\begin{array}{l}\text { Income Distribution } \\
\text { Moderating variable }\end{array}$ & W & GINI & $(+)$ \\
\hline Financial efficiency & $\mathrm{Z}$ & $\begin{array}{l}\text { Operational cost } \\
\text { efficiency }\end{array}$ & $(-)$ \\
\hline
\end{tabular}

\subsection{Model Specification}

The study adopted FGLS panel data regression models to determine the link between Economic growth, Income distribution and poverty level. The summary of data analysis models are given in Table 2.

Table 2. Analysis Models.

\begin{tabular}{|c|c|}
\hline Hypotheses & Analysis Model \\
\hline $\begin{array}{l}\mathrm{H}_{01} \text { : Economic Growth has no significant effect on } \\
\text { poverty levels in EAC member countries. }\end{array}$ & $\begin{array}{l}\text { Simple Regression } \\
\mathrm{Y}_{\mathrm{j}}=\beta_{0}+\beta_{1} \mathrm{X}_{\mathrm{j}-1}+\varepsilon \\
\text { Where: } \\
\mathrm{Y}_{\mathrm{t}}=\text { Poverty Level (Dependent Variable) for the current period } \\
\mathrm{X}_{\mathrm{t}-1}=\text { Real GDP (Economic Growth) for lagged one period } \\
\beta_{0}=\text { Constant } \\
\beta_{1}=\text { coefficient of real GDP } \\
\mathrm{j}=1,2,3,4,5 \text { (Country) } \\
\varepsilon=\text { error term }\end{array}$ \\
\hline $\begin{array}{l}\mathrm{H}_{02} \text { : Income Distribution has no significant mediating } \\
\text { effect on the relationship between economic Growth } \\
\text { and poverty levels in EAC member countries. }\end{array}$ & $\begin{array}{l}\text { Hierarchical Regression } \\
\mathrm{Y}_{\mathrm{j} j}=\beta_{0}+\beta_{1} \mathrm{X}_{\mathrm{jt}-1}+\varepsilon \\
\mathrm{W}_{\mathrm{jt}}=\beta_{0}+\beta_{1} \mathrm{X}_{\mathrm{jt}-1}+\varepsilon \\
\mathrm{Y}_{\mathrm{jt}}=\beta_{0}+\beta_{1} \mathrm{X}_{\mathrm{jt}-1}+\beta_{2} \mathrm{~W}_{\mathrm{jt}-1}+\varepsilon \\
\text { Where: } \\
W_{t}=\text { Income Distribution (Mediating Variable) for current period } \\
\mathrm{W}_{\mathrm{t}-1}=\text { Income Distribution for lagged one period } \\
\beta_{2}=\text { coefficient of Income Distribution } \\
\mathrm{t}-1=\text { lagged one period } \\
\mathrm{t}=\text { Current Period }\end{array}$ \\
\hline $\begin{array}{l}\mathrm{H}_{03} \text { : Financial efficiency has no significant effect on } \\
\text { the link between economic growth and poverty levels } \\
\text { in East African Community countries. }\end{array}$ & $\begin{array}{l}\text { Stepwise Regression } \\
\mathrm{Y}_{\mathrm{j} t}=\beta_{0}+\beta_{1} \mathrm{X}_{\mathrm{jt}-1}+\varepsilon \\
\mathrm{Y}_{\mathrm{jt}}=\beta_{0}+\beta_{1} \mathrm{X}_{\mathrm{jt}-1}+\beta_{2} Z_{\mathrm{jt}-1}+\varepsilon \\
\mathrm{Y}_{\mathrm{jt}}=\beta_{0}+\beta_{1} \mathrm{X}_{\mathrm{jt}-1}+\beta_{2} Z_{\mathrm{jt}-1}+\beta_{3} \mathrm{X}_{\mathrm{jt}-1} . Z_{\mathrm{jt}-1}+\varepsilon \\
\text { Where: } \\
Z_{\mathrm{t}-1}=\text { Financial Efficiency (moderating variable) for lagged one period } \\
\mathrm{X}_{\mathrm{t}-1} . Z_{\mathrm{t}-1}=\text { Product of Real GDP and Financial Efficiency for lagged one period } \\
\beta_{2}=\text { coefficient of Financial Efficiency } \\
\beta_{3}=\text { coefficient of product of Real GDP and Financial Efficiency }\end{array}$ \\
\hline
\end{tabular}




\subsection{Data Analysis}

Diagnostic tests were carried out to examine the conformity of the empirical model to classical least squares assumptions. The process of analyzing the data started start by sorting, classifying, collating and checking for the data completeness. The data were then tabulated in to Microsoft excel and various variables generated. The excel file was then be exported to STATA version 14 for further analysis. The descriptive statistics, which included skewness, minimum and maximum values, standard deviation and mean among others, will be calculated and tabulated. Diagnostic tests were then carried out and finally inferential statistics analysis were performed based on Feasible Generalised Least Squares (FGLS) panel data regression models for overall results and hypotheses testing to ascertain the causal effect link between Economic growth, income distribution and poverty levels in EAC Member Countries. The tests of hypotheses were examined at $95 \%$ confidence level.

\section{Results and Discussion}

The analysis presented in this chapter involved the use of descriptive analysis where mean, standard deviation, minimum, maximum and time series line graphs were used. Diagnostic tests and test of assumptions were also conducted to measure the suitability of the variables for subsequent inferential analysis.

\subsection{Descriptive Analysis}

Descriptive statistics for all the variables were conducted to determine the statistical properties of the data before making an estimation. This involved the use of descriptive statistical tools including mean, standard deviation, minimum, maximum and time series line graphs. The purpose of descriptive analysis was to describe the basic features of the data in the study because they provide simple summaries about the sample and the measures.

Table 3. Summary of Statistics.

\begin{tabular}{llllll}
\hline Variable & Obs & Mean & Std. Dev. & Min & Max \\
\hline $\mathrm{Y}$ & 150 & 60.005 & 16.433 & 31.108 & 86 \\
$\mathrm{X}$ & 150 & $1.62 \mathrm{e}+10$ & $1.51 \mathrm{e}+10$ & $1.23 \mathrm{e}+09$ & $6.18 \mathrm{e}+10$ \\
$\mathrm{~W}$ & 145 & .412 & .091 & .199 & .59 \\
$\mathrm{Z}$ & 150 & .496 & .119 & .117 & .758 \\
\hline
\end{tabular}

Table 3 presented the mean, standard deviation, minimum and maximum point. All the observations (Obs) were 150 with the exception of income distribution. The 150 observations were generated by getting the product of the time period and the number of the countries. Since the time was 30 years, from 1989 to 2018, and there were five countries, the observations were thus $(30 * 5)=150$. However, data for income distribution (W) was only available for 29 years from 1989 to 2017 giving 145 observations $(29 * 5)=145$. The mean for poverty measured by head count ratio for all the five countries considered in the study was $60 \%$. The poverty average mean means that on average for the 30 -year period of the study, poverty level has remained high in East African countries with more than $60 \%$ of the population earning less than 2 USD per day. The standard deviation was 16.43 meaning specific country poverty levels deviated away from the mean by about $16.4 \%$. The minimum poverty level was $31.1 \%$ and the maximum poverty level was $86 \%$. The economic growth was measured by real GDP in USD. The average economic growth was USD 162 billion, the standard deviation was USD 151 billion implying the economic growth of the East African Community countries is spread around the mean by USD 151 billion. The highest economic growth was USD 618 billion and the minimum economic growth was USD 12.3 Billion. Income distribution was measured using the GINI coefficient. The mean income distribution was 0.41 . A GINI coefficient of between 0.1 and 0.3 signified fair distribution of income and a GINI coefficient between above 0.4 signified unequal income distribution. The study suggests that the higher the ratio the higher the unequal the income was distributed. The distribution of income for the five countries for the last 30 years has been about 0.41 implying that the income distribution is unequal. The standard deviation was 0.091 , the maximum income distribution was 0.59 meaning most of the income earned within the country is in the hands of a few people. Financial efficiency was measured by the ratio of cost of the banking sector compared to income earned by the banking sector. This means the higher the ratio the higher the financially inefficient the banking sector. The mean financial efficiency was 49.62 implying the cost of financial intermediation was about $49.62 \%$ as a proportion of the income earned by the banking sector. The higher the cost efficiency ratio, the worse of a country is doing in terms of financial efficiency.

\subsection{Diagnostic Tests}

These tests were carried out to examine the conformity of the empirical model to classical ordinary least squares assumptions. This ensured that the model is fit and robust for the purpose of forecasting. The study tested panel data classical least squares assumptions including normality, heteroscedasticity, multicollinearity, serial correlation, unit root diagnostic tests, cross-sectional correlation.

Shapiro-wilk Test for Normality: All the p-values were less than 0.05 meaning there of a problem of normality hence Least Squares Assumptions of normality of observed variables and residuals is violated hence the study adopted FGLS model for parameter estimation.

Table 4. VIF Test for Multicollinearity.

\begin{tabular}{lll}
\hline Variable & VIF & 1/VIF \\
\hline $\mathrm{W}$ & 9.580 & 0.104 \\
$\mathrm{X}$ & 5.180 & 0.193 \\
$\mathrm{Z}$ & 1.370 & 0.729 \\
Mean VIF & 5.376 & \\
\hline
\end{tabular}


Value Inflation Factor (VIF) Test for Multicollinearity: Results in table 4 showed that all the explanatory variables had a VIF value less than 10 . The explanatory variables therefore showed a lower VIF value. With no explanatory variables showing signs of multicollinearity, the classical least squares panel data model may be appropriate for the analysis. However, for the study to classical least squares panel data model, there should be no violation of heteroscedasticity, unit roots and autocorrelation assumptions.

Modified Wald Test for Heteroscedasticity: The p-value $(0.0000)$ is less than the significance level $(0.05)$ hence the test concluded that there is no constant variance meaning the error terms are heteroskedastic and the OLS assumptions of homoscedasticity is violated. An attempt to remove heteroscedasticity by getting robust standard errors and did not solve the problem. The study therefore ignored the Ordinary Least Squares panel model regression model and adopted FGLS model.

Wooldridge Test for autocorrelation: The results showed that the p-value $(0.0003)$ was less than the significance level (0.05) hence the test rejects the null hypothesis of no autocorrelation implying that the data has strong serial correlation. In addition utilising first order difference data transformation of the variables did not eliminate autocorrelation. Hence, the Ordinary least squares (OLS) assumption of no autocorrelation is violated. The study had to make a choice between Panel Correlated Standard errors (PCSE) model and Feasible Generalised Least Squares (FGLS) model. The study settled on FGLS given that it is used when $\mathrm{T}>\mathrm{n}(\mathrm{T}=30$ years and $\mathrm{n}=5$ countries.

Table 5. Levin-Lin-Chu Unit-root Test.

\begin{tabular}{lll}
\hline Variables & adjusted $\mathbf{t}$ & p-value \\
\hline $\mathrm{Y}$ & 1.5421 & 0.9385 \\
$\mathrm{~W}$ & 0.9348 & 0.8251 \\
$\mathrm{Z}$ & -2.3774 & 0.0087 \\
$\mathrm{X}$ & 1.3855 & 0.9171 \\
\hline
\end{tabular}

Levin-Lin-Chu Unit- root Test: Given the P-values for Poverty (0.9385), income distribution (0.8251), economic growth (0.9171) was greater than the significance level $(0.05)$, the test fails to reject the null hypothesis that panels contain unit roots hence all variables have unit roots meaning the variable is significantly affected by time and may result in spurious regression. In conclusion, given that all the variables showed presence of unit roots with $\mathrm{P}$-values being greater than 0.05., the classical least squares panel model cannot be adopted. The study therefore adopted FGLS model in parameter estimation.

\subsection{Correlation Analysis}

The study adopted correlation analysis to assist explain the association between economic growth, financial deepening, income distribution and financial efficiency and poverty levels among east African community countries. The study also used pairwise Pearson Correlation to establish the relationship among variables. Pairwise Pearson correlation coefficient was generated at 0.05 level of significance. Pearson's correlation (r) indicated that there was a statistically significant negative correlation between income distribution and poverty $(\mathrm{r}=-0.701, \mathrm{p}=0.000<$ $\alpha=0.05$ ). The relationship between economic growth and poverty level was negative and statistically significant $(\mathrm{r}=0.748, \mathrm{p}=.000<\alpha=0.05)$. The association between Financial efficiency and poverty level was negative and statistically insignificant $(\mathrm{r}=-0.119, \mathrm{p}=.0 .154<\alpha=0.05)$. All the explanatory variables were negatively correlated with poverty implying that the explanatory variables (economic growth, financial deepening, income distribution and financial efficiency were inversely related to poverty levels in east African countries (Kenya, Uganda, Tanzania, Burundi and Rwanda).

\subsection{The Effect of Economic Growth on Poverty Levels}

The study sought to test the null hypothesis $\left(\mathrm{H}_{01}\right)$ that economic growth has no significant effect on poverty levels in East African Community countries. The hypotheses test was based on p- values of FGLS regression analysis. The null hypothesis one would be rejected if the p-value generated is less than 0.05 level of significance. Additionally, the null hypothesis was rejected if calculated t-statistic is greater than the critical t-value of +-1.96 . The findings were presented on Table 6.

Table 6. Effect of Economic Growth on Poverty Levels.

\begin{tabular}{ll}
\hline & $(\mathbf{1})$ \\
\hline $\mathrm{X} \_01$ & $\mathbf{Y}$ \\
& $-0.135^{* * * *}$ \\
_cons & $(0.019)$ \\
& $7.122^{* * *}$ \\
Obs. & $(0.401)$ \\
Pseudo $\mathrm{R}^{2}$ & 145 \\
\hline
\end{tabular}

Standard errors are in parenthesis.

$* * * \mathrm{p}<0.01, * * \mathrm{p}<0.05, * \mathrm{p}<0.1$.

Table 6 shows that the p-value associated with economic growth was less than the level of significance $(\alpha=0.05)$ meaning that lagged economic growth has a significant effect on poverty levels in east African countries. Given that, the p-value of economic growth (0.000) was less than 0.05; the null hypothesis $(\mathrm{H} 01)$ that economic growth has no significant effect on poverty levels in East African Community countries was rejected meaning economic growth had a statistically significant effect on poverty levels in East African countries. The simple Regression model (1) equation was thus fitted as follows:

$$
\mathrm{Y}_{\mathrm{jt}}=7.122-0.135 \mathrm{X}_{\mathrm{jt}-1}+\varepsilon
$$

In the fitted model, Intercept term $\beta_{0}$ (7.122) gives the level of poverty when the explanatory variables are held constant at zero. The coefficient of economic growth $\left(\beta_{1}=-0.135\right)$ was negative meaning a growing economy is also associated with falling poverty levels as citizens income improves. 


\subsection{The Mediating Effect of Income Distribution on the Relationship Between Economic Growth and Poverty Levels}

The study sought to test the null hypothesis $\left(\mathrm{H}_{02}\right)$ that income distribution has no significant mediating effect on the relationship between economic growth and poverty levels in EAC member countries. The hypothesis test was based on pvalues of FGLS regression analysis. The null hypothesis two would be rejected if three conditions for mediation were satisfied. For the first condition, the first step of regression, $\mathrm{p}$-value associated with economic growth should be less than 0.05 level of significance ( $p$-value $<0.05$ ). The second condition is that the p-value associated with growth on income distribution generated in the second step of regression should be less than 0.05 level of significance < 0.05 . The third condition is that the $p$-value generated in the third step regression associated with income distribution should be less than 0.05 level of significance and $p$ associated with economic growth should $>0.05$ for there to be complete mediation. However if p-values for economic growth and income distribution generated in step three are all significant, then it is concluded that there is partial mediation. The findings are presented in Table 7.

Table 7. The Mediating effect of Income Distribution on the Relationship between Economic Growth and Poverty Levels.

\begin{tabular}{llll}
\hline & $\mathbf{( 1 )}$ & $\mathbf{( 2 )}$ & $\mathbf{( 3 )}$ \\
\cline { 2 - 4 } & $\mathbf{Y}$ & $\mathbf{W}$ & $\mathbf{Y}$ \\
\hline X_01 & $-0.135^{* * *}$ & $0.115^{* * *}$ & $-0.116^{* * * *}$ \\
& $(0.019)$ & $(0.016)$ & $(0.020)$ \\
W_01 & & & $-0.144^{* *}$ \\
& & & $(0.059)$ \\
_cons & $7.122^{* * *}$ & $-3.477^{* * *}$ & $6.565^{* * *}$ \\
& $(0.401)$ & $(0.399)$ & $(0.474)$ \\
Obs. & 145 & 140 & 145 \\
Pseudo $\mathrm{R}^{2}$ & $\mathrm{z}$ & $\mathrm{z}$ & $\mathrm{z}$ \\
\hline
\end{tabular}

Standard errors are in parenthesis.

$* * * \mathrm{p}<0.01, * * \mathrm{p}<0.05, * \mathrm{p}<0.1$.

Table 7 shows that in the first step of mediation process for hypothesis three test, the $p$-value $(p=0.000)$ associated with economic growth on poverty levels was less than the level of significance $(\alpha=0.05)$. The model was thus estimated as shown in equation (2).

$$
\mathrm{Y}_{\mathrm{jt}}=7.122-0.135 \mathrm{X}_{\mathrm{jt}-1}
$$

Given that the p-values associated with economic growth was less than 0.05 , the second condition for rejection of the null hypothesis 3 was satisfied. In the second step of mediation process for hypothesis 3 , the $\mathrm{p}$ value associated with economic growth $(\mathrm{p}=0.000)$ generated in the second step of regression was less than 0.05 level of significance $(000<$ 0.05 ) meaning economic growth has a significant effect on Income distribution. The model was thus estimated as shown in equation ( 3 ).

$$
\mathrm{W}_{\mathrm{jt}}=-3.477+0.115 \mathrm{X}_{\mathrm{jt}-1}
$$

In the fitted model, Intercept term for model equation (-3.477) gives the level of income distribution when economic growth is held constant at zero. The coefficient of economic growth $\left(\beta_{1}=0.115\right)$ was positive meaning a unitary growth in economy in terms of real GDP, ceteris paribus, is associated with falling income inequality by 0.115 units. Given that the p-value associated with economic growth in the second step of regression was less than 0.05 , the second condition for rejection of the null hypothesis three was thus satisfied.

In the third step of mediation process for hypothesis 3 test, the $\mathrm{p}$-values for economic growth and income distribution (lnx_01, p-value $=0.000$ and Lwu_01, p-value $=0.015$ ) were less than 0.05 level of significance implying that both economic growth and income distribution have a significant effect on poverty levels in EAC member countries. The model was thus estimated as shown in equation (4).

$$
\mathrm{Y}_{\mathrm{jt}}=6.565-0.116 \mathrm{X}_{\mathrm{jt}-1}-0.144 \mathrm{~W}_{\mathrm{jt}-1}+
$$

In the fitted model, Intercept term for model equation (6.565) gives the level of poverty when economic growth and income distribution is held constant at zero. The coefficient of economic growth $\left(\beta_{1}=-0.116\right)$ was negative meaning a unitary growth in economy in terms of real GDP, ceteris paribus, is associated with falling poverty levels by 0.116 units. The coefficient of income distribution $\left(\beta_{2}=-0.144\right)$ was negative, capturing the indirect effect of economic growth on poverty through income distribution and that a unitary increase in income distribution is associated with poverty reduction by 0.144 units, ceteris paribus. Given that the $p$ values associated with economic growth and income distribution were less than 0.05 level of significance, the study concludes that the third condition for rejection of the null hypothesis 3 was thus satisfied.

Given that all the conditions for rejection of hypothesis 2 were satisfied, the study rejected the null hypothesis that Income distribution has no significant effect on the link between economic growth and poverty levels in the East African Community countries. The study therefore concludes that Income distribution has a significant effect on the link between economic growth and poverty levels in East African Community countries.

\subsection{The Moderating Effect of Financial Efficiency on the Relationship Between Economic Growth and Poverty Levels}

The study sought to test the null hypothesis $\left(\mathrm{H}_{03}\right)$ that financial efficiency has no significant moderating effect on the relationship between economic growth and poverty levels in EAC Member countries. The hypotheses test was based on p-values of FGLS regression analysis. The null hypothesis 3 would be rejected if three conditions were satisfied. For the first condition, p-value associated with economic growth in the first step of regression, should be less than 0.05 level of significance ( $p$-value $<0.05$ ). The second condition is that the $\mathrm{p}$-value associated with financial efficiency generated in the second step of regression should be less than 0.05 . The third 
condition is that the $\mathrm{p}$ value associated with product of economic growth and financial efficiency generated in the third step of regression should be less than 0.05 level of significance.. The findings are presented in Table 8 .

Table 8. Moderating Effect of Financial Efficiency on the relationship between economic growth and poverty levels.

\begin{tabular}{llll}
\hline & $\mathbf{( 1 )}$ & $\mathbf{( 2 )}$ & $\mathbf{( 3 )}$ \\
\cline { 2 - 4 } & $\mathbf{Y}$ & $\mathbf{Y}$ & $\mathbf{Y}$ \\
\hline X_01 & $-0.135^{* * *}$ & $-0.135^{* * *}$ & $-0.148^{* * *}$ \\
& $(0.019)$ & $(0.019)$ & $(0.019)$ \\
Z_01 & & 0.011 & 0.409 \\
& & $(0.011)$ & $(0.270)$ \\
XZ_01 & & & -0.018 \\
& & & $(0.012)$ \\
_cons & $7.122^{* * *}$ & $7.132^{* * *}$ & $7.432^{* * *}$ \\
& $(0.401)$ & $(0.400)$ & $(0.418)$ \\
Obs. & 145 & 145 & 145 \\
Pseudo $\mathrm{R}^{2}$ &. $\mathrm{z}$ &. $\mathrm{z}$ &. $\mathrm{z}$ \\
\hline
\end{tabular}

Standard errors are in parenthesis.

$* * * \mathrm{p}<0.01, * * \mathrm{p}<0.05,{ }^{*} \mathrm{p}<0.1$.

In Table 8 presenting the first step of moderation, process for hypothesis 4 test, the overall p-value $(0.000)$ is less than 0.05 meaning that economic growth had a significant effect on poverty levels in EAC member countries. Furthermore, the p-value associated with economic growth $(0.000)$ is less than the level of significance $(0.05)$ meaning economic growth has a significant effect on poverty levels among EAC countries. The model is thus estimated as shown in (5).

$$
\mathrm{Y}_{\mathrm{jt}}=7.122-0.135 \mathrm{X}_{\mathrm{jt}-1}
$$

In the fitted model (1), Intercept term for model equation 7.122 gives the levels of poverty when economic growth is held constant at zero. The coefficient of economic growth $\left(\beta_{1}=-0.135\right)$ is negative meaning a unitary growth in economy in terms of real GDP, ceteris paribus, is associated with falling poverty level by 0.135 units. The first condition for rejection of the null hypothesis 4 is satisfied since p-value associated with economic growth was less than 0.05 level of significance.

In the second step of moderation process for hypothesis 3 test, the p value associated with economic growth (0.000) is less than 0.05 implying that economic growth has a direct significant effect on poverty even in the presence of financial efficiency. However, the p-value associated with financial efficiency $(0.336)$ is not statistically significant meaning that financial efficiency has a weaker effect on poverty levels in EAC countries. The model is thus estimated as shown in (6).

$$
\mathrm{Y}_{\mathrm{jt}}=7.132-0.135 \mathrm{X}_{\mathrm{jt}-1}+0.011 \mathrm{ZJ}_{\mathrm{t}-1}
$$

The intercept term for model equation (6) is 7.132 showing the levels of poverty when both economic growth and financial efficiency was held constant at zero. The coefficient of economic growth $\left(\beta_{1}=-0.135\right)$ is negative meaning a unitary growth in economy in terms of real GDP, ceteris paribus, is associated with falling poverty level by -0.135 units. The coefficient of financial efficiency $\left(\beta_{2}=0.011\right)$ is positive meaning a unitary increase in financial inefficiency, ceteris paribus, is associated with increasing poverty level by 0.011 units. Given that the p-value associated with moderator variable, (financial efficiency) is greater than 0.05 hence not significant, the second condition for rejection of the null hypothesis four is not satisfied.

The Table 8 presented the third step of moderation relationship for hypothesis 3 test. The overall p-value $(0.000)$ is less than 0.05 hence economic growth, financial efficiency and interaction term have a significant effect on poverty levels in EAC countries. In addition, the p-values for economic growth $(\mathrm{p}=0.000)$ measuring direct effect of economic growth on poverty is less than 0.05 meaning than in the presence of financial efficiency, economic growth still has a significant effect on poverty levels among EAC member countries. However, the $\mathrm{p}$ values associated with financial efficiency $(p=0.129)$ and the interaction term (product of economic growth and financial efficiency) (0.141) were greater than the level of significance (0.05). This implies that financial efficiency and the interaction term does not have a significant effect on poverty levels in EAC countries. The model was thus estimated as shown in equation (7).

$$
\mathrm{Y}_{\mathrm{jt}}=7.432-0.148 \mathrm{X}_{\mathrm{jt}-1}+0.409 \mathrm{Z}_{\mathrm{t}-1}-0.018\left(\mathrm{X}_{\mathrm{jt}-1}\right)\left(\mathrm{Z}_{\mathrm{jt}-1}\right)
$$

In equation (7), the intercept term was 7.432 showing the level of poverty when economic growth, financial efficiency and interaction term were held constant at zero. The coefficient of economic growth $\left(\beta_{1}=-0.148\right)$ was negative meaning a unitary growth in economy in terms of real GDP, ceteris paribus, is associated with falling poverty levels by 0.148 units. The coefficient of financial efficiency $\left(\beta_{2}=0.409\right)$ was positive meaning a unitary increase in financial inefficiency, ceteris paribus, is associated with increasing poverty levels by 0.409 units. The coefficient of product of economic growth and financial efficiency $\left(\beta_{3}=-0.018\right)$ gives the moderating effect of financial efficiency on the link between economic growth and poverty levels in East African member countries. The value of $\beta_{3}=-0.018$ means that financial inefficiency weakens the association between economic growth and poverty levels. Given that p- values of financial efficiency and the interaction term were less than 0.05 level of significance, the study concludes that the third condition for rejection of the null hypothesis 4 was not satisfied.

In conclusion, not all conditions for rejection of the null hypothesis were not satisfied hence the study therefore fails to reject the null hypothesis that financial efficiency has no significant effect on the link between economic growth and poverty levels in East African Community member countries. The study therefore concludes that financial efficiency has no significant effect on the link between economic growth and poverty levels in East African Community countries. Financial efficiency is therefore not a moderator for the relationship between economic growth and poverty reduction among EAC member countries. 


\section{Conclusion}

Based on the findings on the relationship between economic growth, income distribution, financial efficiency and poverty levels, the study makes a number of conclusions. First, the study concludes that economic growth has a significant effect on poverty levels in East African Community countries. The coefficient of economic growth was negative meaning a growing economy is also associated with falling poverty level as citizens income improves. The finding implies that improvement of economic growth was crucial in enhancing poverty reduction among countries in east Africa. The findings provide an insight into the significant role that economic growth play in reduction of poverty, especially among EAC member countries. The study also concluded that income distribution has a significant effect on the link between economic growth and poverty levels in East African Community countries. The coefficient of income distribution gives the indirect effect of economic growth on poverty through income distribution. The expected sign of indirect relationship between growth and poverty levels via income distribution was negative which is in conflict with the current findings. It was concluded that income distribution has a significant effect on negative poverty. Given that economic growth has a significant effect on poverty levels in EAC countries, the finding implies that improvement of economic growth was crucial in enhancing poverty reduction among countries in east Africa. In conclusion, the study held that financial efficiency has no significant effect on the link between economic growth and poverty levels in East African Community countries. The positive coefficient of financial efficiency is associated with rising poverty levels. Financial efficiency was measured by cost to income ratio meaning increase in the ratio means falling financial efficiency hence the positive relationship means falling efficiency levels in the banking sector is associated with rising poverty levels. A banking sector that is inefficient cannot play the role of financial intermediation as expected hence rising poverty associated with reduced investment activities. Finally, the study concluded that economic growth, financial deepening, income distribution and financial efficiency have a joint effect on poverty levels in East African Community countries.

The study therefore recommends that the government in general and ministries of planning and economic affairs of EAC countries should put down concrete plans and concerted actions aimed at improving economic growth rates. Additionally, the EAC countries' central banks and the government ministries of finance and treasury should keep the rate of inflation at one digit level to ensure that economic growth is not eroded by increased general price level in the economy. Increased economic growth means improved income for the general population, especially the poor masses.

\section{Acknowledgements}

We would like to recognise valuable contributions from
Professor Mirie Mwangi (PhD), Professor. Josephat Lishenga $(\mathrm{PhD})$, Dr. Kennedy Okiro (PhD) and Mr Michael Ochieng Obuya (PhD Candidate).

\section{References}

[1] Bitler, M., \& Hoynes, H. (2015). Heterogeneity in the Impact of Economic Cycles and the Great Recession: Effects within and across the Income Distribution. American Economic Review, 105 (5), 154-60.

[2] Obuya, M. O., \& Olweny, T. (2017). Effect of Bank's Lending Behaviour on Loan Losses of Listed Commercial Banks in Kenya. International Journal of Management and Commerce Innovations, 5 (1), 135-144.

[3] Sinha, R., Pearson, P., Kadekodi, G., \& Gregory, M. (2017). Income distribution, growth and basic needs in India. Routledge.

[4] World Bank (2019). Afronomics: Analyzing Inequality in Africa. Washington DC. The World Bank group.

[5] Anyanwu, J. (2013). Determining the Correlates of Poverty for Inclusive Growth in Africa Working Paper Series $\mathrm{N}^{\circ} 181$ African Development Bank, Tunis, Tunisia.

[6] Aduda, J., Chogii, R., \& Murayi, M. (2014). The effect of capital market deepening on economic growth in Kenya. Journal of Applied Finance and Banking, 4 (1), 141-159.

[7] Perez-Moreno, S. and Weinhold, D. 2012. Dynamic medium term granger causality between growth and poverty (Unpublished PhD Dissertation), Universidad de Málaga, Spain.

[8] Waiyaki, N. (2013). Financial development, economic growth and poverty in Kenya. University of Nairobi, Unpublished PhD Dissertation.

[9] Kakwani, N., \& Son, H.(2016). Global poverty estimates based on 2011 purchasing power parity: where should the new poverty line be drawn?. The Journal of Economic Inequality, 14 (2), 173-184.

[10] Keho, Y. (2017). The impact of trade openness on economic growth: The case of Cote d'Ivoire. Cogent Economics \& Finance, 5 (1), 1-14.

[11] Williams, H., Adegoke, A., \& Dare, A. (2017). Role of financial inclusion in economic growth and poverty reduction in a developing economy. Internal Journal of Research in Economics and Social Sciences, 7 (5), 265-271.

[12] Singh, R., \& Huang, Y. (2015). Financial deepening, property rights, and poverty: Evidence from Sub-Saharan Africa. Journal of Banking and Financial Economics, 1 (3), 130-151.

[13] Gries, T., Kraft, M., \& Meierrieks, D. (2009). Linkages between financial deepening, trade openness, and economic development: causality evidence from Sub-Saharan Africa. World Development, 37 (12), 1849-1860.

[14] Nzotta, S., \& Okereke, E. (2009). Financial deepening and economic development of Nigeria: An Empirical Investigation.

[15] Keynes, J. (1936). The General Theory of Employment, Interest and Money. London: MacMillan. 
[16] Bradshaw, J., Williams, J., Levitas, R., Pantazis, C., Patsios, D., Townsend, P., Middleton, S. (2000, August). The relationship between poverty and social exclusion in Britain. In 26thPaper prepared for the 26th General Conference of The International Association for Research in Income and Wealth Cracow, Poland, 27 August to 2 September 2000.

[17] Buchanan, J. (1975). Public finance and public choice. National Tax Journal, 28 (4), 383-394.

[18] Fiszbein, A. \& Schady, N (2009). Conditional Cash Transfers: Reducing Present and Future Poverty. Retrieved on 20 May 2018 form http://siteresources.worldban k.org.

[19] Blaug, M. (1997). Competition as an End-State and Competition as a Process. In Not Only an Economist: Economic Theory in Retrospect. 5th ed. Cambridge: Cambridge University Press.

[20] Fosu, A. (2017). Growth, inequality, and poverty reduction in developing countries: recent global evidence. Research in Economics, 71 (2), 306-336.
[21] Levin, J., \& Bigsten, A. (2010). Growth, income distribution, and poverty: a review. Rapport nr.: Working Papers in Economics, (32).

[22] Gakuru, R., \& Mathenge, N. (2012). Poverty, Growth, and Income Distribution in Kenya. The African Growth and Development Policy Modeling Consortium (AGRODEP) Working Paper, 1.

[23] Santos-Paulino, A. (2012). Trade, income distribution and poverty in developing countries: a survey (No. 207). United Nations Conference on Trade and Development.

[24] Popova, L., Popkova, E., Dubova, Y., Natsubidze, A., \& Litvinova, T. (2016). Financial mechanisms of nanotechnology development in developing countries. J. Appl. Econ. Sci, 11 (4), 584-590.

[25] Rossignolo, D. (2017). Taxes, Expenditures, Poverty, and Income Distribution in Argentina. Commitment to Equity Handbook: A Guide to Estimating the Impact of Fiscal Policy on Inequality and Poverty. 